\title{
Revolusi Sistem Pencatatan Tanah Melalui Program Pendaftaran Tanah Sistematis Lengkap (PTSL) Studi Lapangan di Desa Bantul
}

\author{
Sisca Anindya Rachmawati \\ Fakultas Hukum, Universitas Widya Mataram \\ siscaanindyar8@gmail.com
}

\begin{abstract}
Abstrak
Revolusi Pencatatan Tanah Melalui Program Pendaftaran Tanah Sistematis Lengkap (PTSL) merupakan langkah revolusi yang dilaksanakan dalam memberikan Jaminan kepastian akan kepemilikan tanah hal ini dilaksanakan Dalam rangka mengurangi konflik sengketa tanah dan memberi kepastian hukum untuk para pemilik tanah, pemerintah mengeluarkan program untuk mempermudah masyarakat dalam pengurusan sertifikat hak atas tanah ini merupakan hal yang sangat di butuhkan masyarakat adapun berbagai pertimbangan yang dilaksanakan mulai dari mengatasi permasalahan tanah yang hingga hari ini terus terjadi selain itu juga merupakan Jaminan yang diatur sebagai bahagian daripada Konsep negara hukum modern yang meletakan kewenangan pemerintah tidak hanya sekedar menjaga ketertiban atau keamanan melainkan memberikan jaminan kesejahteraan. Implementasi program PTSL di Desa Bantul tahun 2019 telah sesuai dengan asas-asas pendaftaran atas tanah, yaitu sederhana, aman, terjangkau, mutakhir, dan terbuka walaupun dalam beberapa asas tidak sepenuhnya dalam praktiknya dapat mewujudkan asas tersebut. Dalam pelaksanaan program PTSL di Desa Bantul tahun 2019 ditemui ada pada sisi masyarakat yang menilai bahwa waktu yang disediakan untuk mengumpulkan berkas-berkas persyaratan terlalu singkat. Selain itu ada beberapa warga yang kurang mampu memahami prosedur dan persyaratan yang dibutuhkan dalam mengikuti program PTSL di Desa Bantul tahun 2019.
\end{abstract}

Kata Kunci: PTSL, Revolusi, Tanah

\section{A. Pendahuluan}

Cita-cita bangsa Indonesia sebagaimana tercantum dalam Pembukaan UndangUndang Dasar Negara Republik Indonesia Tahun 1945 adalah melindungi segenap bangsa Indonesia dan seluruh tumpah darah Indonesia dan untuk memajukan kesejahteraan umum, mencerdaskan kehidupan bangsa dan ikut melaksanakan ketertiban dunia yang berdasarkan kemerdekaan, perdamaian abadi, dan keadilan sosial. ${ }^{1}$ untuk itu kewajiban negara adalah menjamin setiap hak yang di tuangkan dalam dan oleh konstitusi. ${ }^{2}$ Kepemilikan atas tanah merupakan bagian terpenting yang harus diatur oleh Negara guna menjadi kesejahteraan masyarakat mengingat tanah di Indonesia merupakan tanah yang sangat subur dan merupakan tanah agraris yang mempunyai hasil bumi melimpah yang berupa hasil pertanian maupun hasil tambang. Negara Indonesia juga merupakan negara kepulauan yang mempunyai hasil laut yang beraneka ragam. Dalam konteks pertanahan, tanah adalah permukaan bumi, yaitu

\footnotetext{
${ }^{1}$ Cecep Triwibowo, Etika dan Hukum Kesehatan, Yogyakarta : Nuha Medika, 2014, hal 1

${ }^{2}$ Roni Sulistyanto Luhukay, ed. all, Urgensi Penerapan Local Lockdown Guna Pencegahan Penyebaran Covid 19 Di Tinjau Dalam Perpektif Negara Kesatuan, Adil Indonesia Jurnal, Volume 2 Nomor 2 Juli 2020, Universitas Ngudi Waluyo, hal 38
} 
daratan sebagai tempat manusia untuk mempertahankan kelangsungan hidupnya, tanah juga sebagai tempat suatu negara berdiri untuk memberikan perlindungan kepada rakyatnya guna mewujudkan suatu kehidupan yang sejahtera dan makmur melalui upaya yang dilakukan oleh pemerintah. ${ }^{3}$

Tanah sangat berarti bagi berlangsungnya hidup manusia, karena tanah merupakan kebutuhan pokok bagi manusia yang mengakibatkan manusia sama sekali tidak dapat lepas dengan tanah. Hal ini dapat menyebabkan orang akan menghalalkan berbagai cara untuk dapat memiliki tanah sekalipun tanah tersebut adalah milik orang lain. Penguasaan tanah dengan cara melanggar hukum atau dengan kata lain penguasaan tanah tanpa izin pemegang hak tidak jarang terjadi. Hal ini disebabkan karena luas tanah yang tidak dapat bertambah sedangkan jumlah manusia dan kebutuhan manusia akan tanah terus bertambah. Oleh karena tanah mempunyai ikatan yang sangat kuat dengan manusia, maka perlindungan atas kepemilikan tanah menjadi sesuatu yang sangat dibutuhkan. Hal ini dilakukan agar kepemilikan manusia terhadap tanah dapat memiliki kepastian hukum sehingga dapat terhindar dari permasalahanpermasalahan yang akan timbul dikemudian hari. Pasal 33 ayat (3) Undang-Undang Dasar Negara Republik Indonesia Tahun 1945 selanjutnya disebut UUD Negara Republik Indonesia Tahun 1945 mengandung amanat konstitusional yang mendasar, yakni memberikan penguasaan pada negara atas bumi, air, dan kekayaan alam yang terkandung didalamnya yang penggunaan dan pemanfaatannya harus dapat memberikan kesejahteraan dan kemakmuran yang sebesar-besarnya bagi rakyat. Pasal 33 ayat (3) Undang-Undang Dasar Negara Republik Indonesia Tahun 1945 juga merupakan dasar terbentuknya hukum agraria nasional, yakni Undang-Undang Nomor 5 Tahun 1960 Tentang Peraturan Dasar Pokok-Pokok Agraria (UUPA) yang disahkan pada tanggal 24 September $1960 .^{4}$

Pemerintah merupakan organisasi yang memiliki kekuasaan untuk menetapkan hokum dan bertanggungjawab atas pembangunan Negara. Dalam suatu Negara akan mengalami pertumbuhan penduduk maka kebutuhan atas tanah juga meningkat. Dengan ini dapat dilihat bahwa tanah merupakan hal penting bagi kehidupan manusia. Hal ini seringkali menjadi pemicu munculnya konflik dalam kepemilikan tanah. Maka

\footnotetext{
${ }^{3}$ Asep Hidayat, ed. all, Implementasi Kebijakan Menteri Agraria dan Tata Ruang tentang Percepatan Pelaksanaan Pendaftaran Tanah Sistematis Lengkap, Jurnal Pembanguna Sosial, Vol. 1 No. 1, hal 100 4 Indra Yudha Koswara, Pendaftaran Tanah Sebagai Wujud Kepastian Hukum dalam Rangka Menghadapi Masyarakat Ekonomi Asean (MEA), Jurnal Hukum Positum, Vol. 1 No. 1, hal 24
} 
dari itu sertifikat tanah merupakan alat bukti yang kuat atas kepemilikan tanah. Kepastian hukum kepemilikan atas tanah diatugjan dalam Pasal 19 ayat (1) UUPA menyebutkan bahwa untuk menjamin kepastian hukum atas kepemilikan tanah, maka pemerintah mengadakan kegiatan pendaftaran tanah diseluruh wilayah Republik Indonesia yang diatur lebih lanjut dalam Peraturan Pemerintah Nomor 24 Tahun 1997 tentang Pendaftaran Tanah. Kegiatan pendaftaran tanah merupakan suatu kewajiban yang harus dilakukan oleh pemerintah maupun oleh para pemegang hak atas tanah di seluruh wilayah Indonesia..$^{5}$ Pendaftaran tanah adalah serangkaian kegiatan yang meliputi: 6

a. Pengumpulan, pengolahan, penyimpanan, penyajian data fisik suatu bidang tanah

b. Pengumpulan, pengolahan, penyimpanan, penyajian data yuridis suatu bidang tanah

c. Penerbitan sertifikat sebagai tanda bukti hak

d. Pencatatan terhadap perubahan data fisik dan data yuridis

Namun dalam prakteknya, pelaksanaan pendaftaran tanah masih terdapat beberapa kendala. Diantaranya yaitu biaya pendaftaran tanah yang mahal, masyarakat tidak mengetahui tujuan dilakukannya pendaftaran tanah, masyarakat mengetahui tujuan pendaftaran tanah namun karena pengurusannya yang berbelit-belit mengakibatkan masyarakat enggan untuk mendaftaran tanahnya. Hal ini menyebabkan tidak tercapainya tertib administrasi di bidang pertanahan sehingga masih banyak tanah di Indonesia yang belum terdaftar. ${ }^{7}$

Dalam rangka mengurangi konflik sengketa tanah dan memberi kepastian hukum untuk para pemilik tanah, pemerintah mengeluarkan program untuk mempermudah masyarakat dalam pengurusan sertifikat hak atas tanah. Sesuai dengan Peraturan Menteri Agraria Dan Tata Ruang/Kepala Badan Pertanahan Nasional Republik Indonesia Nomor 12 Tahun 2017 tentang Percepatan Pendaftaran Tanah Sistematis Lengkap (PTSL). Upaya menagatsi konflik tersebut dilaksankan Pendaftaran Tanah Sistematis Lengkap (PTSL) merupakan kegiatan Pendaftaran tanah untuk pertama kali yang dilakukan secara serentak bagi semua obyek pendaftaran tanah di seluruh wilayah

${ }^{5}$ Dian Aries Majiburohman, Potensi Permasalahan Pendaftaran Tanah Sistematis Lengkap, Jurnal Bhumi, Vol. 4 No. 1, hal 88.

${ }^{6}$ Aartje Tehupeiory, Pentingnya PendaftaranTanah di Indonesia, Jakarta : Swadaya Grup, 2012, hal 6-7

${ }^{7}$ Istiqamah, Tinjauan Hukum Legalisasi Aset Melalui Pendaftaran Tanah Sistematis Lengkap (PTSL) terhadap Kepemilikan Tanah, Jurnal Jurisprudentie, Vol. 5 No. 1, hal 226 
Republik Indonesia dalam satu wilayah desa/kelurahan atau nama lainnya yang setingkat itu, yang meliputi pengumpulan dan penetapan data fisik dan data yuridis mengenai satu atau beberapa obyek pendaftaran tanah untuk keperluan pendaftarannya. Badan Pertanahan Nasional (BPN) adalah badan pemerintahan yang membuat program Pendaftaran Tanah Sistematis Lengkap. BPN mensosialisasikan PTSL melalui desa/kelurahan agar dapat membantu masyarakat memanfaatkannya. Program ini dilakukan secara gratis dan massal karena telah dibiayai melalui APBD/APBN.

Langkah revolusioner yang di lakukan pemerintah melalui program Pendaftaran Tanah Sistematis Lengkap (PTSL) sangat berdampak besar terhadap Desa Bantul mengingat desa bantul merupakan salah satu wilayah yang mendapat bagian dalam program Pendaftaran Tanah Sistematis Lengkap (PTSL) 2019. Target PTSL untuk desa Bantul kurang lebih 2500 sertifikat tanah. PTSL di desa Bantul berjalan dengan baik dan lancar karena tingginya antusias warga untuk mengikuti program ini.

\section{B. Telaah Konsep}

Obyek PTSL meliputi seluruh bidang tanah tanpa terkecuali, baik bidang tanah yang belum ada hak atas tanahnya maupun bidang tanah hak, baik merupakan tanah aset Pemerintah/Pemerintah Daerah, tanah Badan Usaha Milik Negara/Badan Usaha Milik Daerah, tanah desa, Tanah Negara, tanah masyarakat hukum adat, kawasan hutan, tanah obyek landreform, tanah transmigrasi, dan bidang tanah lainnya. PTSL merupakan langkah revolusioner yang dilakukan pemerintah melalui Peraturan menteri Agraria dan Tata Ruang Nomor 12 tahun 2017 ini dilaksanakan sebagai langkah dalam percepatan pemberian kepastian hukum dan perlindungan hukum Hak atas Tanah masyarakat secara pasti, sederhana, cepat, lancar, aman, adil, merata dan terbuka serta akuntabel, sehingga dapat meningkatkan kesejahteraan dan kemakmuran masyarakat dan ekonomi negara, serta mengurangi dan mencegah sengketa dan konflik pertanahan.

\section{Metode Penelitian}

Metode penelitian meruapakan cara ilmiah untuk mendapatkan data yang valid dengan tujuan dapat ditemukan, dikembangkan, dan dibuktikan, suatu pengetahuan tertentu sehingga dapat digunakan untuk memahami, memecahkan, dan 
mengantisispasi masalah" ini pada dasarnya penelitian ini menguanakan penelitian dengan penggabungan antara penelitian hukum normatif dengan adanya penambahan dari berbagai unsur-unsur empiris. Dalam metode penelitian normatif-empiris ini juga mengenai implementasi ketentuan hukum normatif (undang-undang) dalam aksinya disetiap peristiwa hukum tertentu yang terjadi dalam suatu masyarakat ${ }^{9}$. Dalam penelitian ini mengkaji fakta yang ada di masyarakat, yaitu Program Pendaftaran Tanah Sistematis Lengkap (PTSL) di Desa Bantul. Sedangkan disebut normatif karena penelitian ini mengkaji kesesuaian fakta yang ada di masyarakat terhadap peraturanperaturan tertulis atau hukum positif yang ada di Indonesia.. ${ }^{10}$

\section{Pembahasan}

\section{Konsep implementasi Revolusi Pencatatan Tanah Melalui Program Pendaftaran Tanah Sistematis Lengkap (PTSL).}

Produk akhir dari kegiatan pendaftaran tanah berupa sertipikat hak atas tanah, mempunyai banyak fungsi bagi pemiliknya, dan fungsinya itu tidak dapat digantikan dengan benda lain. Pertama, sertipikat hak atas tanah berfungsi sebagai alat pembuktian yang kuat. Inilah fungsi yang paling utama sebagaimana disebut dalam Pasal 19 ayat (2) huruf c UUPA. ${ }^{11}$ Jaminan kepastian akan kepemilikan tanah oleh hukum sangat di butuhkan masyarakat dengan berbagai pertimbangan mulai dari mengatasi permasalahan tanah yang hingga hari ini terus terjadi serta di harapkan akan upayah penyelesaiannya. Jaminan diatur sebagai bahagian daripada Konsep negara hukum modern yang meletakan kewenangan pemerintah tidak hanya sekedar menjaga ketertiban atau keamanan (Rust en Orde) tetapi juga mengupayakan kesejahteraan umum (Bustuursqorg) ${ }^{12}$. Jaminan tersebut merupakan

\footnotetext{
${ }^{8}$ Sugiyono, Metode Penelitian Pendidikan Pendekatan Kuantitatif, Kualitatif, dan R\&D, Bandung : Alfabeta, 2014, hal 6

${ }_{9}^{9}$ Parta Setiawan, Metode Penelitian Hukum-Pengertian, Macam, Normatif, Empiris, Pendekatan, Data, Analisa Para Ahli diakses dari https://www.gurupendidikan.co.id/metode-penelitian-hukum/ pada tanggal 12 Januari 2021 pukul 15.18 WIB

${ }^{10}$ Ishaq, Metode Penelitian Hukum dan Penulisan Skripsi, Tesis, serta Disertasi, Jakarta : Alfabeta, 2017, hal 20

${ }^{11}$ Adrian Sutedi, Sertipikat Hak atas Tanah, Jakarta : Sinar Grafika, 2011, hal 96

${ }^{12}$ Ridwan HR, Hukum Administrasi Negara, Jakarta : Raja Grafindo, 2006, hal 14
} 
hal yang sangat pokok yang di keluarkan oleh pemerintah melalui berbagai bentuk regulasi hal ini merupakan penetuan nasib hidup masyarakat Indonesia. ${ }^{13}$

Untuk itu Keberadaan negara Indonesia sebagai negara hukum harus di buktikan dengan eksisnya, Pemerintah Indonesia dalam merepon permasalahan yang terjadi ${ }^{14}$ pemerintah merespon dengan menerbitkan Peraturan Menteri Agraria dan Tata Ruang/Kepala Badan Pertanahan Nasional Nomor 12 Tahun 2017 Tentang Percepatan Pendaftaran Tanah Sistematis Lengkap (PTSL). Yang berdasarkan pada UUD NRI 1945 dan Undang Undang Republik Indonesia Nomor 5 Tahun 1960 tentang Peraturan Dasar Pokok Pokok Agraria, Peraturan Pemerintah Republik Indonesia Nomor 24 Tahun 1997 tentang Pendaftaran Tanah. Peraturan Presiden Nomor 17 Tahun 2015 tentang Kementerian Agraria dan Tata Ruang, Peraturan Presiden Nomor 20 Tahun 2015 tentang Badan Pertanahan Nasional, Instruksi Presiden Republik Indonesia Nomor 2 tahun 2018 tentang Percepatan Pendaftaran Tanah Sistematis Lengkap di Seluruh Wilayah Indonesia, Peraturan Pemerintah Nomor 24 Tahun 1997 tentang Pendaftaran Tanah ini dilaksanakan guna menjawab amanah konstitusi serta terjadinya antara produk hukum yang satu dengan yang lainnya sehingga terdapat keselarasan dalam pembangunan administrasi yang tertib dan jaminan kepastian yang menyeluruh. Langkah upaya pemerintah dalam membangun revusi pencatatan tanah Percepatan Pelaksanaan Pendaftaran Tanah secara Sistematis Lengkap (PTSL) diatur dalam Peraturan Menteri Agraria Tata Ruang/Kepala Badan Pertanahan Nasional Nomor 1 Tahun 2017 tentang perubahan atas Peraturan Menteri Agraria dan Tata Ruang/Kepala Badan Pertanahan Nasional Nomor 35 Tahun 2016 tentang Percepatan Pelaksanaan Pendaftaran Tanah Sistematis Lengkap. Latar belakang perubahan peraturan tersebut dinyatakan dalam konsiderannya di bawah perkataan "menimbang", yaitu:

1) Bahwa Peraturan Menteri Agraria dan Tata Ruang/Kepala Badan Pertanahan Nasional Nomor 35 Tahun 2016 tentang Percepatan Pelaksanaan Pendaftaran

\footnotetext{
${ }^{13}$ Roni Sulistyanto Luhukay, Prioritas Kebijakan Ekonomi Dan Kesehatan Di Massa Pandemic Covid 19, Jurnal Restorative Justice, Fakultas Hukum Universitas Mussamus Merauke Papua, Volume 4 No 2, November 2020, hlm 101

${ }^{14}$ Roni Sulistyanto Luhukay, Indenpendensi Kekuasaan Kehakiman Pasca Amandemen UUD 1945 Dan Relevansinya Bagi Penegakan Hukum Berkeadilan, Jurnal Jurisprudentie UIN Alauddin Makassar, Volume 6 No 1 Juni 2019, hlm 136
} 
Tanah Sistematis Lengkap, belum dapat dilaksanakan karena terdapat hal-hal prisip dan substantive yang belum diatur;

2) Bahwa berdasarkan pertimbangan sebagaimana dimaksud dalam huruf a, perlu menetapkan Peraturan Menteri Agraria dan Tata Ruang/Kepala Badan Pertanahan Nasional tentang Perubahan Atas Peraturan Menteri Agraria dan Tata Ruang/Kepala Badan Pertanahan Nasional Nomor 35 Tahun 2016 tentang Percepatan Pelaksanaan Pendaftaran Tanah Sistematis Lengkap.

Suatu Regulasi yang di jadikan suatu hukum merupakan suatu perintah dari penguasa yang dituangkan dalam bentuk perundang- undangan, unsur yang terpenting dari hukum adalah "perintah" (command). Oleh karena itu hukum bersifat tetap, logis, dan tertutup (closed logical system), di mana keputusan-keputusan wajib memperhatikan nilai-nilai yang baik atau buruk ${ }^{15}$.kebijakan yang di keluarkan oleh pemerintah merupakan langkah yang sangat revolusioner menginggat masyarakat hingga hari ini merindukan Percepatan Pelaksanaan Pendaftaran Tanah Sistematis Lengkap.

Dalam implementasinya kegiatan pendaftaran tanah sistematis lengkap selanjutnya disebut PTSL dilaksanakan oleh Panitia Ajudikasi Pendaftaran Tanah Sistematis Lengkap. Berdasarkan Pasal 5 ayat (2) Peraturan Menteri Agraria dan Tata Ruang/Badan Pertanahan Nasional Nomor 1 Tahun 2017 Susunan Panitia Ajudikasi Pendaftaran Tanah Sistematis Lengkap terdiri dari:

a. Ketua Panitia merangkap anggota, yang dijabat oleh seorang pegawai Kantor Pertanahan;

b. Wakil ketua yang membidangi infrastruktur agraria merangkap anggota, yang dijabat oleh pegawai Kantor Pertanahan yang memahami urusan infrastruktur pertanahan;

c. Wakil ketua yang membidangi hubungan hukum agraria merangkap anggota, yang dijabat oleh pegawai Kantor Pertanahan yang memahami urusan hubungan hukum pertanahan;

d. Sekretaris, yang dijabat oleh pegawai Kantor Pertanahan;

e. Kepala Desa/Kelurahan setempat atau seorang Pamong Desa/Kelurahan yang ditunjuknya; dan

15 Bernard L. Tanya, ed. all, Teori Hukum (Strategi tertib Manusia Lintas Ruang dan Generasi), Yogyakarta : Genta Publishing, 2010, hlm 120 
f. Anggota dapat ditambah dari unsu Kantor Pertanahan sesuai dengan kebutuhan.

Dalam implemantasi pelaksanaan pendafataran tanah juga mengacuh pada Pasal

6 Peraturan Menteri tersebut menyatakan bahwa Panitia Ajudikasi Pendaftaran

Tanah Sistematis Lengkap wajib melaksanakan hal hal sebagai berikut di bawah ini:

a. Menyiapkan rencana kerja percepatan pendaftaran tanah;

b. Mengumpulkan Data Fisik dan dokumen asli Data Yuridis semua bidang tanah yang ada di wilayah yang bersangkutan serta memberikan tanda penerimaan dokumen kepada pemegang hak atau kuasanya;

c. Memberikan asistensi terhadap kelengkapan persyaratan bukti kepemilikan tanah sesuai dengan aturan yang berlaku;

d. Memeriksa kebenaran formal Data Fisik dan data Yuridis alat bukti pemilikan atau penguasaan tanah;

e. Mengumumkan Data Fisik dan Data Yuridis bidang tanah yang sudah dikumpulkan

f. Memafisilitasi penyelesaian sengketa antara pihak-pihak yang bersangkutan mengenai data yang diumumkan; Mengesahkan hasil pengumuman sebagaimana dimaksud dalamm huruf e yang akan digunakan sebagai dasar pembukuan hak atau pengusulan pemberian hak serta pendaftaran hak;

g. Menyampaikan laporan secara periodic dan menyrahkan hasil kegiatan kepada Kepala Kantor Pertanahan; dan

h. Melakukan supervise pelaksanaan dan hasil pekerjaan Satuan Tugas Fisik (Satgas Fisik) dan Satuan Tugas Yuridis (Satgas Yuridis).

Pendaftaran tanah yang dilaksanakan meliputi pengukuran, pemetaan dan pembukuan tanah, pendaftaran hak-hak atas tanah dan peralihannya, pemberian surat tanda bukti hak yang berlaku sebagai alat pembuktian yang kuat, hal ini termuat dalam Pasal 19 UUPA. Pelaksanaan pendaftaran tanah meliputi kegiatan pendaftaran tanah untuk pertama kali dan pemeliharaan data pendaftaran tanah, hal ini termuat dalam Pasal 11 Peraturan Pemerintah Nomor 24 Tahun 1997. Kegiatan pendaftaran tanah untuk pertama kali meliputi: 1) pengumpulan dan pengolahan data fisik; 2) pembuktian hak dan pembukuannya, penerbitan sertifikat, penyajian data fisik dan data yuridis, penyimpanan daftar umum dan dokumen. Kegiatan pengumpulan dan pengolahan data fisik meliputi kegiatan pengukuran dan 
pemetaan, termasuk di dalamnya adalah pembuatan peta dasar pendaftarann, penetapan batas bidang-bidang tanah, pengukuran dan pemetaan bidang-bidang tanah dan pembuatan peta pendaftaran, pembuatan daftar tanah, serta pembuatan Surat Ukur. Pengukuran dan pemetaan dimaksud dilaksanakan bidang demi bidang dengan satuan wilayah desa/kelurahan. Sebelum dilaksanakan pengukuran, batasbatas tanah harus dipasang tanda batas dan ditetapkan batas-batasnya.

Melalui asas kontradiksi delimitasi (dihadiri dan disetujui oleh pemilik tanah yang letaknya berbatasan langsung) dengan bidang tanah dimaksud. Kegiatan tersebut dengan tujuan untuk menjamin kepastian hukum hak atas tanah, maka diselenggarakan pendaftaran tanah di seluruh wilayah RI.

Percepatan pelaksanaan PTSL sebagaimana termuat dalam Pasal 3 ayat (3) Peraturan Menteri Agraria dan Tata Ruang/Badan Pertanahan Nasional Nomor 1 Tahun 2017 dilakukan dengan tahapan:

a. Penetapan lokasi kegiatan percepatan Pendaftaran Tanah Sistematis Lengkap;

b. Pembentukan dan penetapan Panitia Ajudikasi pendaftaran Tanah Sistematis Lengkap;

c. Penyuluhan;

d. Pengumpulan dan pengolahan Data Fisik dan Data Yuridis bidang tanah;

e. Pemeriksaan tanah;

f. Pengumuman Data Fisik dan Data Yuridis;

g. Penerbitan keputusan pemberian Hak atas Tanah;

h. Pembukuan Hak atas Tanah;

i. Penerbitan Sertipikat Hak atas Tanah; dan/atau

j. Penyerahan sertipikat Hak atas Tanah.

Tahapan tersebut dilaksanakan sesuai dengan subjek, objek, alas hak dan proses Pendaftaran Tanah Sistematis Lengkap (PTSL). Dalam hal ini terjadi beberapa perbedaan tahapan dengan Pasal 3 ayat (4) Peraturan Menteri Agraria dan Tata Ruang/Badan Pertanahan Nasional Nomor 12 Tahun 2017, yaitu:
a. perencanaan dan persiapan;
b. penetapan lokasi kegiatan PTSL;
c. pembentukan dan penetapan Panitia Ajudikasi PTSL;
d. penyuluhan;
e. pengumpulan Data Fisik dan Data Yuridis bidang tanah; 
f. pemeriksaan tanah;

g. pengumuman Data Fisik dan Data Yuridis bidang tanah serta pembuktian hak;

h. penerbitan keputusan pemberian atau pengakuan Hak atas Tanah;

i. pembukuan dan penerbitan Sertipikat Hak atas Tanah; dan

j. penyerahan Sertipikat Hak atas Tanah.

Perbedaan tahapan tersebut tidak memengaruhi pelaksanaan PTSL karena pada dasarnya esensinya sama yaitu untuk percepatan dalam melakukan pendaftaran tanah secara sistematis dan untuk mendapatkan kepastian hukum serta perlindungan hukum. Salah satu tahapan dari kegiatan pendaftaran tanah adalah kegiatan pengumpulan data fisik. Pengumpulan data fisik adalah kegiatan mengumpulkan data fisik yang meliputi:

a. Penetapan batas bidang tanah,

b. Pengukuran batas bidang tanah,

c. Pemetaan bidang tanah,

d. Pengumuman data fisik

e. Menjalankan prosedur dan memasukkan data dan informasi yang berkaitan dengan data fisik bidang tanah di aplikasi KKP36 (Komputerisasi Kegiatan Pertanahan) dengan berpedoman kepada ketentuan peraturan perundangundnagan yang mengatur tentang pengukuran dan pemetaan bidang tanah;

Pengaturan dan penerapan Peraturan Menteri Agraria dan Tata Ruang/Kepala Badan Pertanahan Nasional Nomor 12 Tahun 2017 Tentang Percepatan Pendaftaran Tanah Sistematis Lengkap (PTSL) yang tidak sesuai dengan kaidah kaidah hukum berpotensi menimbulkan kekacouan hukum dalam kehidupan masyarakat dan tindakan sewenang-wenang. ${ }^{16}$ Untuk itu pengaturan ini diatur secara jelas dan tepat mulai dari substansi hukum sampai pada teknis di lapangan.

\section{Implementasi Program Pendaftaran Tanah Sistematis Lengkap (PTSL) di Desa Bantul}

Program pendaftaran tanah sistematis lengkap di Desa Bantul, Kecamatan Bantul, Kabupaten Bantul merupakan kegiatan yang dilakukan dengan tujuan untuk

\footnotetext{
${ }^{16}$ Roni Sulistyanto Luhukay, Karakteristik Tanggung Gugat Perusahaan Terhadap Lingkungan Dalam Menciptakan Kesejateraan Rakyat, Junal Meta Yuridis Universitas PGRI Semarang, Volume 2 No 1 Tahun 2009, hal 26
} 
memberikan jaminan kepastian hukum atas kepemilikan tanah oleh warganya. Mulanya pada akhir 2016 Pemerintah Desa Bantul mengajukan permohonan tertulis kepada Badan Pertanahan Negara (BPN) Kabupaten Bantul untuk melakukan sertifikasi tanah secara masal. Inisiatif tersebut dilatarbelakangi oleh banyaknya warga Desa Bantul yang tanahnya belum bersertifikat, ataupun bukti kepemilikan tanahnya masih berupa Leter C. Menjawab permohonan tersebut BPN Kabupaten Bantul kemudian mempercayakan kepada Pemerintah Desa Bantul untuk turut melaksanakan program pensertifikasian tanah dengan melalui Program Nasional Agraria (Prona) tahun 2017. Program tersebut kemudian berganti nama menjadi program Pendaftaran tanah Sistematis Lengkap (PTSL) ${ }^{17}$.

Hak-hak atas tanah yang didaftarkan di Desa Bantul sebagian besar adalah hak milik yang masih terdaftar dengan surat bukti kepemilikan berupa Leter C. Dan sebagian besar dari itu adalah tanah yang diperoleh melalui sistem waris atau tanah warisan dari orang tua atau saudaranya. Sebetulnya hak-hak atas tanah yang bisa dimintakan sertifikasi adalah hak milik atas tanah, Hak Guna Usaha (HGU), Hak Guna Bangunan (HGB), Hak Pakai, Tanah Wakaf yang merupakan obyek pendaftaran tanah. Namun demikian pada saat proses pendaftaran tanah secara sistematis di Desa Bantul pada umumnya adalah sertifikat hak milik atas tanah.

Menindaklanjuti kepercayaan dari Badan Pertanahan Nasional Kabupa-ten Bantul untuk melaksanakan program percepatan pendaftaran secara sistematis, maka Pemerintah Desa Bantul membuat perencanaan untuk melaksanakan program tersebut. Perencanaan dimulai dengan membentuk panitia pelaksana program tersebut

Tahapan- Tahapan dalam pelaksanaan Program Pendaftaran Tanah Sistematis Lengkap (PTSL) :

1) Sosialisasi dan Penyuluhan

Panitia bekerja mensosialisasikan kepada masyarakat di wilayah Desa Bantul bahwa akan ada program pensertifikatan program pendaftran tanah sistimatis lengkap (PTSL) secara masal.

Penyuluhan dilakukan oleh Kepala Kantor Pertanahan beserta Panitia Ajudikasi PTSL, Satgas Fisik dan Satgas Yuridis dengan melibatkan aparat

${ }^{17}$ Hasil wawancara dengan Kasi Pemerintahan Desa Bantul tanggal 1 Februari 2021 di Kantor Desa Bantul 
Desa/Kelurahan/ Kecamatan/Pemerintah Daerah/aparat penegak hukum Polri, maupun Kejaksaan, TNI serta tokoh masyarakat. Penyuluhan dilakukan kepada masyarakat, aparat Desa/Kelurahan/ Kecamatan/Pemerintah Daerah, yang ada dalam 1 (satu) Desa/Kelurahan yang ditetapkan sebagai lokasi PTSL. Dalam sosialiasi tersebut diumumkan bagi warga masyarakat Desa Bantul yang berkeinginan untuk mengikuti program PTSL dimohon segera menyiapkan persyaratan-persyaratan yang diperlukan guna keperluan pendaftaran atas tanah tersebut sesuai waktu yang telah ditentukan. Persyaratan-persyaratan yang dibutuhkan dalam kegiatan pendaftaran ini seperti: Kartu Keluarga (KK), Kartu Tanda Penduduk (KTP), keterangan waris bagi yang nama dalam Letter C sudah meninggal dunia, materai, dan kelengakapan-kelengkapan administrasi untuk pemberkasan lainnya. Jika pemilik atau nama yang tertera pada Letter C sudah meninggal dunia maka yang mempunyai hak waris adalah turun darahnya. Sosialisasi tersebut juga dimaksudkan untuk memberikan pemahaman kepada masyarakat agar tercipta tertib administrasi pertanahan di Kabupaten Bantul. ${ }^{18}$ Setelah diadakan sosialisasi dan pemahaman kepada masyarakat tentang adanya Program PTSL, kemudian Pemerintah Desa Bantul membentuk Pokmas (kelompok masyarakat). Pokmas dibentuk untuk mengawal program PTSL di lapangan, misalnya membantu menyiapkan dan melakukan pengukuran tanah, dan mengumpulkan berkas-berkas administrasi yang meliputi Kartu Keluarga, Kartu Tanda Penduduk, Kutipan Letter C desa, keterangan waris dan berita acara pembagian warisan. ${ }^{19}$

2) Penetapan Lokasi dan Jumlah Bidang Warga yang mengurus dan mengikuti proses pendaftaran Program PTSL tahun 2019 di Desa Bantul berasal dari berbagai pedukuhan yang berada di Desa Bantul. Secara rinci jumlah pendaftar per pedukuhan dapat dilihat pada Tabel 1.Secara keseluruhan jumlahnya adalah 1072 orang. Terbanyak berasal dari pedukuhan Gandekan, dan tersedikit dari pedukuhan Kresen. Rata-rata jumlah pendaftar per pedukuhan adalah sebanyak 98 orang.

3) Pengumpulan dan pengolahan Data Yuridis bidang tanah 
Pengumpulan data yuridis dilaksanakan oleh Satgas Yuridis dan dapat dibantu oleh Pengumpul Data Yuridis dari unsur kelompok masyarakat atau profesi. Pengumpulan data yuridis meliputi pengumpulan data dan alat bukti kepemilikan/penguasaan tanah, baik bukti tertulis, keterangan saksi dan/atau pernyataan yang bersangkutan dari setiap bidang tanah. Petugas pengumpul data yuridis menyerahkan dan mengumpulkan Formulir Pendaftaran. Kegiatan pengumpulan data yuridis dapat dikoordinasikan dengan Pemerintah Desa/Kelurahan dan dapat dilakukan secara kolektif dengan melibatkan partisipasi masyarakat di lokasi PTSL. Kegiatan pengumpulan data yuridis sedapat mungkin mengoptimalkan partisipasi masyarakat.

Jenis alat bukti dalam rangka pengumpulan data yuridis antara lain meliputi:

a. Alas hak, misalnya bukti perpajakan yang dimiliki sebelum tahun 1960;

b. Bukti peralihan hak, misalnya akta jual beli atau surat pernyataan di bawah tangan

c. Apabila peserta PTSL tidak dapat menyediakan bukti kepemilikan baik yang berupa bukti tertulis maupun bentuk lain yang dapat dipercaya, pembuktian hak dapat dilakukan tidak berdasarkan bukti kepemilikan melainkan berdasarkan bukti penguasaan fisik yang dilakukan oleh peserta PTSL dan pendahulunya.

Kegiatan pengumpulan data yuridis dapat dilaksanakan sebelum, sesudah atau bersamaan dengan pelaksanaan kegiatan pengukuran batas bidang tanah. Instansi yang terlibat dalam proses pendaftaran tanah secara sitematis di Desa bantul, selain Pemerintah Desa bantul sendiri, juga Pemerintah Kecamatan Bantul dan Kantor Badan Pertanahan Kabupaten Bantul. Pemerintah Desa Bantul dan Pemerintah Kecamatan Bantul dalam proses pendaftaran tanah ini bertindak sebagai instansi yang bertugas untuk melakukan validasi dan verifikasi data terkait dengan data kepundudukan dan kepemilikan tanah warga. Apabila telah dilakukan verifikasi dan validasi serta telah dibuatkan berita acaranya selanjutnya berkas dibawa ke Kantor Badan Pertanahan Nasional Kabupaten Bantul untuk dimintakan pembuatan akta sertifikat tanah yang bersangkutan. Pihak Badan 
Pertanahan Kabupaten Bantul inilah yang berwenang untuk mengeluarkan sertipikat hak milik atas tanah. ${ }^{20}$

4) Pengambilan Data fisik

Dalam pengambilan data fisik atau keterangan mengenai letak, batas dan luas bidang tanah dan satuan rumah susun yang didaftar, termasuk keterangan mengenai adanya bangunan atau bagian bangunan diatasnya, penentuan data dilakukan oleh Satgas Fisik (Satuan Petugas Fisik) secara per bidang sesuai dengan data yuridis yang telah diperoleh perdesa/perdukuhan/perkelurahan. Pengukuran tersebut dilakukan mulai dari Bulan Mei sampai dengan Bulan Agustus. Dalam pengambilan datanya, dilakukan berdasarkan Petunjuk Teknis (Juknis) Pelaksanaan PTSL yaitu dengan menggunakan 4 metode sebagai berikut:

1) Metode Terestrial

Pengukuran bidang tanah dengan metode terestrial adalah pengukuran secara langsung di lapangan dengan cara mengambil data ukuran sudut dan jarak, yang dikerjakan dengan teknik-teknik pengambilan data trilaterasi (jarak), triangulasi (sudut) atau triangulaterasi (sudut dan jarak) dengan menggunakan alat pita ukur, distometer, teodolit dan elektronik total station.

2) Metode Fotogrametris;

Metode fotogrametris merupakan salah satu metode pengukuran yang dapat mendukung percepatan pendaftaran tanah sistematis lengkap. Metode ini hanya dapat dilaksanakan untuk daerah terbuka, non-pemukiman, nonkomersial, non-industri.

3) Metode Pengamatan Satelit

Pengukuran bidang tanah menggunakan metode pengamatan satelit adalah pengukuran dengan menggunakan sinyal-sinyal gelombang elektromagnetik yang dipancarkan dari minimal 4 satelit menggunakan alat GPS geodetic. Pengukutan bidang tanah dengan GPS dapat dilakukan dengan metode Real Time Kinematik (RTK)/CORS, Post-Processing, Point Precisse Positioning (PPP) maupun Stop and Go.

4) Metode Kombinasi

Metode pengukuran yang merupakan perpaduan dari pengukuran terestris, fotogrametris dan/atau pengamat satelit. Hasil dari pelaksanaan pengukuran 
bidang tanah dan pengumpulan informasi bidang tanah dituangkan dalam Gambar Ukur (GU) atau Surat Ukur.

5) Pemeriksaan tanah dan Penerbitan keputusan pemberian Hak atas Tanah

Dalam hal ini dilakukan pemeriksaan terhadap kelengkapan berkas permohonan. Satgas Yuridis mengadakan penelitian dan pengkajian mengenai status tanah, riwayat tanah dan hubungan hukum antara tanah yang dimohon dengan peserta PTSL serta kepentingan lainnya. Selanjutnya peninjauan fisik atas tanah yang dimohon mengenai penguasaan, penggunaan/keadaan tanah serta batas-batas bidang tanah yang dimohon kemudian mengumpulkan keterangan/penjelasan dari para pemilik tanah yang berbatasan. Setelah itu dicek kesesuaian penggunaan tanah yang dimohon dengan Rencana Tata Ruang Wilayah setempat. Kemudian satgas memberikan pendapat, pertimbangan dan kesimpulan dapat tidaknya diberikannya hak, yang dituangkan dalam Risalah Penelitian Data Yuridis. Penggunaan surat pernyataan sebagai alat bukti dalam rangka pelaksanaan kegiatan PTSL, digunakan setelah dapat memastikan bahwa keadaan alat buktinya yang diberikan ternyata tidak lengkap atau tidak ada sama sekali.

6) Pengumuman Data Fisik dan Data Yuridis

Hasil pemeriksaan tanah yang menyimpulkan dapat dibukukan dan atau diterbitkannya Sertifikat hak atas tanah atas satu bidang tanah diumumkan dalam papan pengumuman di Kantor Pertanahan dan/atau Kantor desa/kelurahan dan/atau Sekretariat RT/RW lokasi bidang tanah tersebut selama 14 hari, dengan tujuan untuk diketahui khalayak masyarakat dan memberi kesempatan kepada pihak-pihak yang berkepentingan untuk menyampaikan keberatan jika ada keberatan. Hal ini merupakan perbedaan yang sangat signifikan antara PTSL dengan pendaftaran tanah sistematis biasa terkait jangka waktu. Apabila dalam waktu 14 hari ada yang merasa keberatan maka data mengajukan keberatan atau dapat menggugat ke Pengadilan Tata Usaha Negara (PTUN), namun apabila selama dalam jangka waktu 14 hari tidak ada sanggahan maupun keberatan maka akan diterbitkan sertifikat yang kemudian disahkan pada hari ke 15. Tahapan ini merupakan implementasi asas publisitas pendaftaran tanah

7) Pembukuan Hak atas Tanah 
Setelah pengumuman berakhir dan tidak ditemukan adanya sanggahan dari masyarakat maka data fisik akan dituangkan dan dicetak dalam Surat Ukur sedangankan data yuridis akan dituangkan ke dalam Buku Tanah yang kemudian Ketua Ajudikasi menandatangani dibagian Buku Tanah.

8) Penerbitan dan Penyerahan Sertipikat Hak atas Tanah

Panitia Ajudikasi Bidang Yuridis akan menyiapkan atau mencetak Sertifikat Hak Atas Tanah yang kemudian Kepala Kantor Pertanahan akan menandatangi sertifikat hak atas tanah atau dapat mendelegasikan kewenangan penandatanganan Sertifikat kepada Ketua Panitia Ajudikasi Percepatan. Kemudian Panitia Ajudikasi Percepatan menyerahkan Sertifikat Hak Atas Tanah kepada pemegang hak atau kuasanya dengan mencatatnya dalam daftar isian penyerahan sertifikat. Dalam penyerahan sertifikat PTSL ini dilakukan di balai desa pada obyek pendaftaran tanah..

Dalam hal pembiayaan pelaksanaan program PTSL Pemerintah Desa Bantul merujuk pada Peraturan Bupati Bantul Nomor 75 Tahun 2017 Tentang Pembebanan Pembiayaan Persiapan Pendaftaran Tanah Sistematis Lengkap. ${ }^{21}$ Dalam Pasal 3 Perbup Bantul No. 75 tahun 2017 dinyatakan bahwa pembia-yaan program PTSL dibebankan pada Anggaran Pendapatan dan Belanja Negara, namun untuk kegiatan persiapan dibebankan kepada masyarakat. Kegiatan persiapan yang dimaksudkan adalah kegiatan penyiapan dokumen, pengadaan patok dan materi, dan operasional petugas desa. Penyiapan dokumen merupakan kegiatan pengadaan dokumen yang berupa surat pernyataan yang dibuat oleh pemilik atau yang menguasai bidang tanah yang dimohonkan. Dokumen tersebut minimal berisi keterangan tentang tidak adanya sengketa, riwayat pemilikan/penguasaan tanah, tanah yang dikuasai/dimiliki bukan merupakan tanah asset Pemerintah/Pemerintah Daerah/Pemerintah Desa, dan penguasaan tanah secara periodik. Dalam hal pembiayaan patok dan materi yang dimaksudkan adalah pembiayaan kegiatan pengadaan Patok Batas sebagai tandabatasbatas bidang tanah sebanyak 3 (tiga) buah dan pengadaan Materai 6000 paling sedikit 1 (satu) buah sebagai pengesahan Surat Pernyataan. Sedangkan dalam hal pembiayaan operasional petugas yang dimaksudkan adalah pembiayaan kegiatan yang meliputi biaya penggandaan dokumen pendukung, biaya pengangkutan dan pemasangan patok, dan 
transportasi Petugas Desa dari Kantor Desa ke Kantor Pertanahan KabupatenBantul dalam rangka perbaikan dokumen yang diperlukan. ${ }^{22}$

Setelah mengkaji pelaksanaan program PTSL di Desa Bantul maka dapat dikatakan bahwa pelaksaanaan program tersebut di Desa Bantul telah dilakukan sangat membantu masyarakat ${ }^{23}$ dan sesuai dengan asas-asas pendaftaran atas tanah sebagaimana tercantum dalam Pasal 2 Peraturan Pemerintah Nomer 24 Tahun 1997 Tentang Pendaftaran Tanah, yaitu sederhana, aman, terjangkau, mutakhir, dan terbuka. Argumentasi dari kesesuaian pelaksanaan program PTSL di Desa Bantul dengan asasasas tersebut adalah sebagai berikut:

1. Asas Sederhana.

Asas ini dimaksudkan agar ketentuan-ketentuan pokoknya maupun prosedurnya dengan mudah dapat dipahami oleh pihak-pihak yang berkepentingan, terutama para pemegang hak atas tanah. Dalam pelaksanaan program PTSL di Desa Bantul dapat dikatakan sederhana karena syarat-syarat yang diperlukan sesuai dengan yang dibutuhkan dalam pembuatan sertifikat tanah. Tidak ada syarat-syarat tambahan yang tidak berkaitan dengan pembuatan sertifikat tanah. Selain itu Pemerintah Desa juga telah membentuk Pokmas di masing-masing pedukuhan sehingga bagi pendaftar yang belum memahami alur dan persyaratan untuk mengikuti program PTSL dapat bertanya pada Pokmas di pedukuhannya serta meminta bantuan dalam melengkapi beekas-berkas persyaratan administratif dan dalam melaksanakan pengukuran tanah. Pokmas juga berperan dalam mensosialiasikan program PTSL kepada warga terkait dengan prosedur dan syarat pendaftaran.

\section{Asas Aman}

Asas ini untuk menunjukkan bahwa pendaftaran tanah perlu diselenggarakan secara teliti dan cermat sehingga hasilnya dapat memberikan jaminan kepastian hukum sesuai tujuan pendaftaran tanah itu sendiri. Namun lebih dari itu, dalam pelaksanaan PTSL di Desa Bantul sendiri, sampai sekarang masih belum dapat dipastikan bahwa asas aman tersebut dapat terwujud meskipun telah diverifikasi dan divalidasi secara

${ }^{22}$ Pasal 3-7 Perbup Bantul No. 75 Tahun 2017

23 Tanggapan masyarakat terhadap adanya program PTSL di Desa Bantul menurut keterangan Kasi Pemerintahan mereka sangat senang karena terbantu dengan biaya yang murah. Hal ini dikarenakan berdasarkan Pasal 14 ayat (2) Peraturan Menteri Agraria dan Tata Ruang/Kepala Badan Pertanahan Nasional Republik Indonesia Nomor 35 Tahun 2016 tentang Percepatan Pelaksanaan Pendaftaran Tanah Sistematis Lengkap terhadap warga desa yang kurang mampu. Masyarakat juga merasa senang karena proses dalam pelaksanaan pendaftran tanah secara sistematis untuk pertama kali di Desa Bantul dapat dilakukan dengan cepat 
berjenjang, mulai dari tingkat desa di Kantor Desa Bantul, kemudian kembali diverifikasi dan divalidasi kembali di tingkat kecamatan, yaitu di Kantor Kecamatan Bantul, untuk kemudian berkas-berkas yang lolos verifikasi dan validasi dikirimkan ke BPN Bantul. Dalam praktiknya juga adanya proses pengumuman data fisik maupun yuridis yang sebelumnya dilakukan sebelum penerbitan hak atas tanah dimana ini menjadi proses yang bertujuan untuk diketahui khalayak masyarakat dan memberi kesempatan kepada pihak-pihak yang berkepentingan untuk menyampaikan keberatan jika ada keberatan.

Sebenarnya pada praktiknya, penerapan asas aman baru dapat terlihat apabila terdapat suatu kasus kesalahan pengetikan baik itu tempat obyek tanah, nama subyek tanah atau bahkan luas obyek tanah yang tercatat dalam sertifikat yang dalam hal ini ditemukan setelah adanya transaksi selanjutnya di hadapan PPAT dan belum berlangsung penyerahan sertifikat kepada pemohon.

Namun, jika sertifikat telah diserahkan kepada pemohon PTSL, dan ternyata terjadi kesalahan ketik atau penulisan yang demikian, secara keamanan, sertifikat tersebut tetap aman seperti halnya tanah yang diukur ulang setelah dilakukan pemecahan atau pembangunan dengan catatan tidak ada suatu permasalahan yang ditemukan. Meski begitu, hal tersebut tetap saja tidak bisa dikatakan sebagai suatu yang teliti dan apakah kasus yang demikian bisa dikatakan sebagai bentuk jaminan hukum. Oleh karena itu dalam melaksanakan percepatan PTSL, harus tetap mengutamakan asas aman (teliti dan cermat dalam pengerjaannya) agar tidak menyebabkan kesalahan akibat buman error.

3. Asas Keterjangkauan,

Asas ini dimaksudkan agar pelayanan yang diberikan dalam rangka penyelenggaraan pendaftaran tanah harus bisa terjangkau oleh para pihak yang memerlukan, khususnya bagi golongan ekonomi lemah. Pelaksanaan program PTSL di Desa Bantul, asas terjangkau ini hanya terjadi dalam proses pendaftaran di BPN saja. Halhal diluar itu, seperti syarat dalam turun waris yang meliputi akta kematian, pajak dan lainya, harus menggunakan biaya sendiri oleh pemohon sehingga pemohon harus mengeluarkan biaya yang lainya.

4. Asas Mutakhir

Asas ini dimaksudkan kelengkapan yang memadai dalam pelaksanaannya dan kesinambungan dalam pemeliharaan datanya. Selain itu data yang tersedia harus 
menunjukkan keadaan yang mutakhir. Kemutakhiran dalam pelaksanaan program PTSL di Desa Bantul terlihat dari pengumpulan data-data kependudukan yang mutakhir seperti pengempulan kartu keluarga, ktp, dan data- data lainnya, serta pelaksanaan pengukuran langsung oleh petugas BPN pada saat pendaftaran tersebut. Hal tersebut mendukung terpelihara-nya data pendaftaran tanah secara terus menerus dan berkesinam-bungan, sehingga data yang tersedia di Kantor BPN Bantul selalu sesuai dengan keadaan nyata di lapangan dan ter-update sesuai kondisi terbaru.

\section{Asas Terbuka}

Asas ini berkaitan dengan tersedianya data yang benardan dapat diperoleh setiap saat. Dalam arti para pihak yang berkepentingan baik itu masyarakat, pihak swasta maupun pemerintah sendiri dapat dengan mudah memperoleh informasi yang dibutuhkan berkaitan dengan data-data pendaftaran tanah. Pelaksanaan program PTSL di Desa Bantul dapat dikatakan sesuai dengan asas terbuka karena data-data yang tercantum dalam berkas-berkas yang manjadi syarat mengikuti program PTSL dikumpulkan dan disimpan di kantor BPN Bantul sehingga setiap saat pemilik atau pihak-pihak yang berkepentingan dapat meminta informasi yang ada pada berkas-berkas tersebut kepada BPN Bantul.

Dalam pelaksanaan PTSL di Desa Bantul memang tidak sepenuhnya berjalan dengan lancar. Hal ini ditemukan dengan adanya hambatan yang terjadi dalam pelaksanaan program PTSL di Desa Bantul. Secara gris besar hambatan yang dialami oleh masyarakat yang menjadi peserta PTSL adalah kendala waktu yang dirasa sebagian warga cukup singkat untuk melengkapi berkas-berkas persyaratan yang diperlukan. Akan tetapi hal tersebut bisa diatasi dengan kerja kerasnya Pokmas yang ada di setiap pedukuhan dibantu pemohon sendiri dan sikap pro aktif dari semua pihak. Hambatan lainnya yang ditemui oleh masyarakat Desa Bantul adalah kadangkala ada kekurang pahaman, kurangnya pengertian terhadap proses pelaksanaan pendaftaran tanah dalam program ini.Namun akhirnya hambatan yang berasal dari masyarakat tersebut bisa diselesaikan melaluibantuan Pokmas yang memberikan penjelasan dan pemahaman kepada masyarakat sehingga masyarakat menjadi paham. Hal tersebut terjadi karena memang beberapa warga memiliki tingkat pendidikan rendah. ${ }^{24}$

Dibentuknya Pokmas-pokmas yang ada di tiap-tiap pedukuhan di Desa Bantul dapat membantu Pemerintah Desa Bantul dalam menjembatani permasalahan- 
permasalahan yang ada dimasyarakat mengenai adanya kekurangpahaman masyarakat dan proses pengumpulan administrasi yang diperlukan dalam proses pelaksanaan program PTSL di Desa Bantul.

Sedangkan dari sisi kendala hukum atau keadaan yang membatasi, menghalangi atau mencegah pencapaian sasaran terkait permasalahan hukum, disebabkan oleh 2 faktor yaitu peristiwa hukum dan perbuatan hukum.

1) Peristiwa hukum

Terjadi apabila peristiwa atau kejadian tersebut dapat menimbulkan akibat hukum, antara pihak-pihak yang mempunyai hubungan hukum.

Dalam pelaksanaan PTSL Tahun 2019 di Desa Bantul, yang termasuk peristiwa hukum adalah masalah waris. Hal ini dapat menjadi kendala bagi terlaksananya PTSL karena apabila bidang tanah yang akan didaftarkan pada PTSL merupakan bidang tanah yang cara perolehannya berupa peralihan hak dan nama yang tercantum dalam Letter C sudah meninggal lama dan baru diajukan, ketika pendaftaran tanah (pemutihan) maka dibutuhkan surat keterangan kematian, surat keterangan waris (ditandatangi oleh seluruh ahli waris), jumlah ahli waris, syarat turun waris yang keseluruhanya dapat memakan waktu yang lama. Oleh karena itu, Panitia Ajudikasi Percepatan atau perangkat BPN memberikan solusi alternatif berupa dicantumkannya nama bersama di atas sertifikat yang dimohonkan, sehingga apabila suatu saat seluruh ahli waris sudah dapat berkumpul dan ingin membagi tanahnya akan lebih mudah karena sudah tertera haknya (tanah bisa di bagi sesuai dengan ketentuan yang telah disepakati). Sehingga, dari hal tersebut dapat dikatakan bahwa hambatan terbesarnya terletak pada harus adanya surat keterangan waris yang disetujui dan ditandatangi seluruh ahli waris, sedangkan ahli warisnya berada pada kota atau bahkan negara yang berbeda. Disamping itu pula, masyarakat sebagai pemohon juga dibebankan lagi biaya-biaya untuk mengurus segala macam persyaratan tersebut seperti mengurus akta kematian, pembayaran pajak dan lain sebagainya. Untuk mengurus pajak pajak dan mencari surat keterangan waris ini membutuhkan banyak waktu sedangkan PTSL dibatasi oleh jangka waktu target sehingga dalam proses turun waris ini banyak permohonan pendaftaran tanah yang tertinggal untuk diproses.

2) Perbuatan hukum 
Tindakan yang oleh hukum diberi akibat hukum berdasarkan anggapan bahwa subjek hukum yang melakukannya memang mengkehendaki timbulnya akibat hukum yang bersangkutan. Dalam hal pelaksanaan PTSL di Desa Bantul, perbuatan hukum yang dimaksud misalnya adalah jual beli. Dalam hal jual beli, apabila belum memiliki sertifikat tanah maka dapat menggunakan Letter C. Sebelum tahun 1997 atau sebelum diundangkannya Peraturan Pemerintah Nomor 24 Tahun 1997 tentang Pendaftaran Tanah maka dalam melakukan jual beli tanah harus ada bukti berupa kwitansi, segel dan Letter C. Sedangkan setelah tahun 1997 atau setelah diundangkannya Peraturan Pemerintah Nomor 24 Tahun 1997 tentang Pendaftaran tanah maka dalam melakukan jual beli tanah harus ada Akta Jual Beli (AJB) dengan 2 orang saksi dan materai. Sehingga atas hal tersebut, kendala terbesarnya adalah ketika melakukan jual beli dan masih menggunakan kwitansi dan segel, maka pihak pelaksana PTSL akan merasa kesulitan untuk mengurus proses pendaftaran tanahnya.

3) Bukti Kepemilikan (Letter C) Hilang.

Letter C sendiri adalah Buku yang disimpan aparat desa atau biasanya oleh Sekretaris Desa (Sekdes). Buku ini dapat dijadikan bukti kepemilikan atas tanah karena tanah yang tercatat dalam buku tersebut sudah dikuasai bertahun-tahun.

Selama ini masyarakat desa atau masyarakat adat lebih mengenal bukti kepemilikan tanah berupa dokumen letter C. Dokumen Letter C tersebut awalnya hanya berfungsi sebagai catatan kelurahan/desa untuk tanah yang dimiliki masyarakat adat secara turun temurun. Akan tetapi masyarakat sebagai pemegang hak atas tanah hanya diberikan bukti berupa Letter C/Girik/Petok D sebagai alat bukti pembayaran pajak atas kepemilikan tanah tersebut.

Kekuatan hukum Girik sebagai alat pembuktian hak penguasaan tanah menurut Undang-Undang nomor 5 tahun 1960 mengenai Peraturan Dasar Pokok-Pokok Agraria bahwa Girik bukan merupakan bukti penguasaan tanah setelah berlakunya UUPA, namun kekuatan pembuktiannya dalam hukum beracara perdata tidak hapus. Kekuatan pembuktian Letter $\mathrm{C}$ tidak bersifat sempurna. Letter $\mathrm{C}$ tidak cukup kuat untuk dijadikan alat bukti tunggal sehingga harus mendapat dukungan dari beberapa bukti lain. Sehingga untuk memastikan pemilik tanah yang dimaksud tidak cukup hanya dibuktikan dengan salinan / copy Letter C saja, akan tetapi diperlukan dokumen lain untuk memastikan kepemilkan tersebut, antara lain : 
1. Girik/Petok/ atas tanah tersebut

2. PBB serta bukti pembayarannya

3. Surat Keterangan Riwayat Tanah dari Kelurahan

4. Surat tidak sengketa

Dan saat ini dengan adanya Undang-Undang Pokok Agraria yang ditindak lanjuti dengan adanya Peraturan Pemerintah Nomor 10 Tahun 1961 yang kemudian diganti dengan Peraturan Pemerintah Nomor 24 Tahun 1997 tidak mungkin lagi diterbitkan hak-hak yang tunduk kepada Kitab Undang-Undang Hukum Perdata ataupun yang akan tunduk kepada hukum adat setempat kecuali menerangkan bahwa hak-hak tersebut merupakan hak adat. Hal yang menjadi isi dalam letter $\mathrm{C}$ tanah ini sebagai berikut :

1. Nomor buku C

2. Kohir (surat atau daftar penetapan pajak)

3. Persil (sebidang tanah dengan ukuran tertentu), ada catatan atau tata arsip pemetaan tanah dalam buku dan peta tanah di kantor kelurahan atau kantor kepala desa.

4. Nomor letter $\mathrm{C}$ tanah dan persil menunjukkan titik batas tertentu satu bidang tanah sesuai dengan data yang tercatat.

5. Kelas tanah (suatu letak tanah dalam pembagiannya atau biasa disebut juga blok)

6. Kelas desa (suatu kelas tanah yang digunakan untuk membedakan antara darat dengan tanah sawah, atau juga antara tanah yang produktif dengan non produktif, ini dilakukan untuk menentukan pajak yang akan dipungut.

7. Daftar pajak bumi (terdiri dari nilai pajak, luasan tanah dalam meter persegi, dan juga tahun pajak).

8. Nama pemilik letter $C$ tanah (mencakup nama pemilik dari pemilik awal hingga pemilik yang terakhir)

9. Nomor urut pemilik

Dengan dasar tersebut pula, petugas Kantor Pertanahan atau BPN dapat melihat siapa yang berhak atas kepemilikan tanah yang belum bersertifikat disuatu desa. Sehingga apabila letter C hilang maka akan sangat sulit bagi pihak BPN utuk melaksanakan PTSL, karena Letter C merupakan bukti permulaan untuk mendapatkan tanda bukti hak atas tanah secara yuridis yaitu sertifikat. Oleh karena 
itu, apabila Letter C hilang maka peserta PTSL harus terlebih dahulu mengurus kehilangan Letterr $\mathrm{C}$ terebut agar selanjutnya dapat memenuhi syarat utama pendaftaran PTSL. Hal ini menjadi hambatan dalam proses pemberkasan dalam memenuhi administrasi pendaftaran tanah, Letter $\mathrm{C}$ hilang ini sebenarnya menjadi hambatan hampir di semua desa yang menjadi peserta PTSL tidak hanya di Desa Bantul $^{25}$

\section{E. Penutup}

Dari penelitian yang telah dilakukan maka dapat diambil beberapa kesimpulan sebagai berikut:

1. implementasi Revolusi Pencatatan Tanah Melalui Program Pendaftaran Tanah Sistematis Lengkap (PTSL) merupakan langkah revolusi yang dilaksanakan guna memberikan Jaminan kepastian akan kepemilikan tanah oleh hukum ini merupakan hal yang sangat di butuhkan masyarakat dengan berbagai pertimbangan mulai dari langkah mengatasi permasalahan tanah yang hingga hari ini terus terjadi selaian itu juga merupakan Jaminan yang diatur sebagai bahagian daripada Konsep negara hukum modern yang meletakan kewenangan pemerintah tidak hanya sekedar menjaga ketertiban atau keamanan melaikan memberikan jaminan kesejahteraan.

2. Implementasi program PTSL di Desa Bantul tahun 2019 telah sesuai dengan asas-asas pendaftaran atas tanah, yaitu sederhana, aman, terjangkau, mutakhir, dan terbuka walaupun dalam beberapa asas tidak sepenuhnya dalam praktiknya dapat mewujudkan asas tersebut. Dalam pelaksanaan program PTSL di Desa Bantul tahun 2019 tidak ditemui kendala yang berarti. Kendala yang ditemui ada pada sisi masyarakat yang menilai bahwa waktu yang disediakan untuk mengumpulkan berkas-berkas persyaratan terlalu singkat. Selain itu ada beberapa warga yang kurang mampu memahami prosedur dan persyaratan yang dibutuhkan dalam mengikuti program PTSL di Desa Bantul tahun 2019. Hal tersebut teratasi oleh keberadaan Pokmas yang dibentuk untuk melakukan pendampingan terhadap masyarakat dalam mengikuti program PTSL di Desa Bantul tahun 2019.

25 Hasil wawancara dengan Satgas Yuridis Desa Bantul tanggal 4 Februari 2021 di Kantor Badan Pertanahan Nasional Kabupaten Bantul 


\section{F. Daftar Pustaka}

\section{Buku}

Aartje Tehupeiory, Pentingnya PendaftaranTanah di Indonesia, Jakarta : Swadaya Grup, 2012;

Adrian Sutedi, Sertipikat Hak atas Tanah, Jakarta : Sinar Grafika, 2011;

Bernard L. Tanya, ed. all, Teori Hukum (Strategi tertib Manusia Lintas Ruang dan Generasi), Yogyakarta : Genta Publishing, 2010;

Cecep Triwibowo, Etika dan Hukum Kesehatan, Yogyakarta : Nuha Medika, 2014;

Ishaq, Metode Penelitian Hukum dan Penulisan Skripsi, Tesis, serta Disertasi, Jakarta : Alfabeta, 2017;

Ridwan HR, Hukum Administrasi Negara, Jakarta : Raja Grafindo, 2006;

Sugiyono, Metode Penelitian Pendidikan Pendekatan Kuantitatif, Kualitatif, dan R\&D, Bandung : Alfabeta, 2014.

2. Artikel, jurnal, internet

Asep Hidayat, ed. all, Implementasi Kebijakan Menteri Agraria dan Tata Ruang tentang Percepatan Pelaksanaan Pendaftaran Tanah Sistematis Lengkap, Jurnal Pembanguna Sosial, Vol. 1 No. 1;

Dian Aries Majiburohman, Potensi Permasalahan Pendaftaran Tanah Sistematis Lengkap, Jurnal Bhumi, Vol. 4 No. 1;

Indra Yudha Koswara, Pendaftaran Tanah Sebagai Wujud Kepastian Hukum dalam Rangka Menghadapi Masyarakat Ekonomi Asean (MEA), Jurnal Hukum Positum, Vol. 1 No. 1;

Istiqamah, Tinjauan Hukum Legalisasi Aset Melalui Pendaftaran Tanah Sistematis Lengkap (PTSL) terhadap Kepemilikan Tanah, Jurnal Jurisprudentie, Vol. 5 No. 1;

Parta Setiawan, Metode Penelitian Hukum-Pengertian, Macam, Normatif, Empiris, Pendekatan, Data, Analisa Para Abli diakses dari https://www.gurupendidikan.co.id/metode-penelitian-hukum/ pada tanggal 12 Januari 2021 pukul 15.18 WIB;

Roni Sulistyanto Luhukay, Indenpendensi Kekuasaan Kehakiman Pasca Amandemen UUD 1945 Dan Relevansinya Bagi Penegakan Hukum Berkeadilan, Jurnal Jurisprudentie UIN Alauddin Makassar, Vol. 6 No. 1; Karakteristik Tanggung Gugat Perusahaan Terbadap Lingkungan Dalam Menciptakan Kesejateraan Rakyat, Junal Meta Yuridis Universitas PGRI Semarang, Vol. 2 No. 1; , Prioritas Kebijakan Ekonomi Dan Kesehatan Di Massa Pandemic Covid 19, Jurnal Restorative Justice, Fakultas Hukum Universitas Mussamus Merauke Papua, Vol. 4 No. 2; ed. all, Urgensi Penerapan Local Lockdown Guna Pencegaban Penyebaran Covid 19 Di Tinjau Dalam Perpektif Negara Kesatuan, Adil Indonesia Jurnal, Universitas Ngudi Waluyo, Vol. 2 No. 2.

3. Peraturan Perundang-undangan

Undang-Undang Dasar 1945

Perbup Bantul No. 75 Tahun 2017 